\title{
Potential Analysis of Mediterranean Forestry for Offsetting GHG Emissions at Regional Level: Evidence from Valencia, Spain
}

\author{
Edgar Lorenzo-Sáez *Did, Jose-Vicente Oliver-Villanueva ${ }^{\mathbb{D}}$, Victoria Lerma-Arce $\mathbb{D}^{\text {, }}$, Celia Yagüe-Hurtado \\ and Lenin Guillermo Lemus-Zúñiga
}

Information and Communication Technologies vs Climate Change Research Group, Campus de Vera, ITACA Research Institute, Universitat Politècnica de València, 46022 Valencia, Spain; joolvil@upv.es (J.-V.O.-V.); vlerma@upv.es (V.L.-A.); ceyahur@upv.edu.es (C.Y.-H.); lemus@upvnet.upv.es (L.G.L.-Z.)

* Correspondence: edlosae@upv.es

check for updates

Citation: Lorenzo-Sáez, E.; Oliver-Villanueva, J.-V.; Lerma-Arce, V.; Yagüe-Hurtado, C.; Lemus-Zúñiga, L.G. Potential Analysis of Mediterranean Forestry for Offsetting GHG Emissions at Regional Level: Evidence from Valencia, Spain. Sustainability 2021, 13, 4168. https: / / doi.org/10.3390/su13084168

Academic Editor: Ken Byrne

Received: 23 February 2021

Accepted: 3 April 2021

Published: 8 April 2021

Publisher's Note: MDPI stays neutral with regard to jurisdictional claims in published maps and institutional affiliations.

Copyright: (c) 2021 by the authors. Licensee MDPI, Basel, Switzerland. This article is an open access article distributed under the terms and conditions of the Creative Commons Attribution (CC BY) license (https:/ / creativecommons.org/licenses/by/ $4.0 /)$.
Abstract: Forest management is an untapped tool, yet to realize its full potential to fight against climate change. The capability of forests to act as carbon sinks makes them a key resource to reduce $\mathrm{CO}_{2}$ concentration in the atmosphere. However, carbon which has been fixed can be suddenly emitted again as a consequence of disturbances such as pests or wildfires. Mediterranean plant phenology, climatic conditions, and the accumulation of fuel biomass due to abandonment of traditional forest uses generate a scenario prone to large wildfires and consequently large greenhouse gases (GHG) emissions. The abandonment could be offset by considering the economic value of forest ecosystem services, principally carbon fixation. Nevertheless, currently existing forest carbon markets consider only anthropogenic fixation based on a business as usual scenario without disturbances that cannot be applied to Mediterranean forest reality. Thus, a methodology to monetize carbon fixed has been developed and applied. A range between 55.5 and 250 million $€$ produced by the monetization of 16.5 million potential carbon credits has been obtained based on anthropogenic avoided emissions produced over a 10 year-period. Thereby, the potential for offsetting emissions of the pilot region was between $1.2 \%$ and $5.6 \%$ of total diffuse GHG emissions. Consequently, sustainable forest management represents an important opportunity to combat climate change, taking advantage of the margin of improvement that the Mediterranean forests currently have to avoid GHG emissions through forest fire prevention silviculture.

Keywords: Mediterranean forestry; GHG; carbon; climate change; wildfires

\section{Introduction}

Forests play a key role in climate change mitigation by sequestrating atmospheric carbon dioxide $\left(\mathrm{CO}_{2}\right)$ in new forestland and in extant forests [1]. According to the Intergovernmental Panel on Climate Change (IPCC) [2], carbon stored in terrestrial ecosystems is distributed betwee three compartments: living plant biomass (stem, branches, foliage, roots); plant detritus (fallen branches and cones, forest litter, tree stumps, tree tops, $\operatorname{logs}$ ); and soil (organic mineral, surface and deep mineral soil). The terrestrial biosphere has the potential to mitigate between 10 and 20\% of the fossil fuel emissions by 2050 [1]. Following Vine et al. [3], forests can tackle climate change in three main ways:

(a) afforestation, reforestation or forest management to increase the carbon fixed by forests;

(b) bioenergy or biomaterials as substitutive of fossil fuels or more energy intensive materials [4-6]; and

(c) preservation of existing forests to avoid or reduce emissions due to anthropogenic disturbances (deforestation) or natural disturbances (pests, hurricanes, snowfalls or wildfires) through preventive and sustainable forest management.

Forest fires have social, ecological and economic costs [7]. In ecological terms, preserving existing forests is especially important because forests act as both sinks or sources 
of greenhouse gas (GHG) emissions [8,9]. Natural forest disturbances (mainly wildfires) emit $9 \mathrm{Gt} \mathrm{C}$ per year worldwide, which represents approximately $30 \%$ more than the GHG emissions from fossil fuels [10]. Wildfire risk is clearly the result of the interaction between human activities, largely a result of mismanagement over decades or centuries, ecological domains, and climate [11]. In fact, in especially vulnerable areas such as the Mediterranean, wildfire risk is increasing mainly due to three causes [12]:

(a) number of years with increased fire risks;

(b) season length with severe meteorological conditions that increase fire risks; and

(c) extreme events (e.g., total number of days with Fire Weather Index (FWI) $>45$ and especially episodes with FWI $>45$ for seven consecutive days) during summer or drought seasons are increasing.

In 2009 alone, approximately 434,927 ha were burnt in the EU Mediterranean region [13]. For this reason, wildfires are one of the most detrimental environmental issues in the Mediterranean basin.

Mediterranean plant phenology and climatic conditions generate a scenario very prone to large wildfires and consequently large amounts of GHG emissions. In addition, the accumulation of fuel biomass due to abandonment of traditional forest uses affects severity and magnitude of wildfires, as Marchi et al. [14] demonstrate in Mediterranean Country, and therefore causes even higher emissions. This abandonment is partly a result of the low economic revenues of Mediterranean forests and it could be solved by considering the ecosystem services of forests, principally carbon fixation.

There are ways to quantify in money terms the carbon fixed by forest systems. The most commonly used mechanism is carbon markets [15]. A carbon market is a financial solution for GHG reduction through emissions trading [16]. In other words, it is a market in which carbon credits are obtained and sold within defined standards for GHG prevention or reduction [17]. There are two different types of carbon markets [18]:

(a) regulatory compliance market: used by companies and governments that by law have to account for their GHG emissions and is regulated by mandatory national, regional or international carbon reduction regimes.

(b) voluntary market: carbon credits trade is on voluntarily basis.

In Europe, the most important compliance market is the European Union Emissions Trading Systems (EU ETS) for direct GHG emissions [19]. EU ETS works at setting a cap on the total amount of GHG emissions that can be emitted by installations and receiving a part of its emissions in free allocated allowances forced to reduce the rest. At least half of the auction revenues of EU ETS must be used to reduce GHG emissions for mitigation or adaptation to climate change in the EU and third countries [19]. But even though wildfires can be a major focus of GHG emissions mainly in the European Mediterranean regions, none of this money goes to wildfire prevention [16].

On the other hand, the most important type of voluntary carbon market is based on forest fixation [20]. The total carbon credits generated in forest based voluntary carbon markets correspond to the difference in carbon stock regarding business as usual (BaU) due to different silvicultural practices (reforestation after clear cutting, tree plantations on former agricultural land etc.). Nevertheless, despite the existence of some preservation actions in the same carbon markets (as in the EU ETS carbon market) [19], especially aimed at the preservation of tropical forests, most of the forest actions to compensate GHG emitted of voluntary carbon markets are limited methodologically to reforestation or tree plantations actions, as for example in Spain [21]. Nevertheless, this approach does not include sustainable forest management to reduce wildfire risk, to improve forest health or to provide the sustainability of non-economical ecosystem services of forests.

Therefore, this approach is not useful in large areas of the Mediterranean basin, especially in dry regions with a low rate of forest management due to the low economic value (with high rates of rural abandonment) and yearly accumulation of fuel biomass. 
These forests are specifically prone to wildfires, even more under severe weather conditions foreseen with climate change that will increase burned area and fire severity [22-25].

Another system for monetize the carbon stored in the forest sector is Reducing Emissions from Deforestation and forest Degradation (REDD +). The REDD + initiative applies a market-based approach to reducing GHG emissions from deforestation and forest degradation [26]. The difference between the carbon stock of forests under historical deforestation and forest degradation rates and the actual C-stock achieved by forest conservation measures will be compensated financially. The difference in C-stocks is provided by a system of measurement, reporting, and verification (MRV). However, the cost of MRV is too high in countries with low deforestation compared to the economic compensation of REDD + [26]. This means that REDD + only has an impact in developing countries where historically there has been high deforestation ratios and its economic compensation is worth it [26].

There is a high potential for annual fixation by Mediterranean forests to mitigate climate change that needs to be estimated and valued because it can become a great source of GHG emission [12]. But for this to occur, it is necessary to develop a monetization methodology with a new approach adapted to Mediterranean forest types, which takes into account prevention measures to reduce GHG emissions by natural disturbances, mainly wildfires.

The overall objective of this research is to analyze the potential of Mediterranean forestry for offsetting GHG emissions at a regional level with local level resolution. To achieve this, the specific aims are:

1. to quantify $\mathrm{CO}_{2}$ fixation in the total biomass of forests in the study area under Mediterranean conditions;

2. to develop and to apply a methodology to monetize the $\mathrm{CO}_{2}$ eq. fixation of forests under Mediterranean conditions;

3. to compare total forest $\mathrm{CO}_{2}$ fixation with total $\mathrm{GHG}$ emissions at the regional level in the case study region; and

4. to evaluate the potential of Mediterranean forestry for offsetting GHG emissions.

\section{Materials and Methods}

The materials and methods section is structured in the six steps described in the diagram of Figure 1. Thus, in first place the annual carbon fixation was calculated for small and tall trees. Then, the total carbon stored till today was quantified by municipality. After that, a monetization model was developed and applied to obtain the potential carbon saved (PCS) and the potential carbon credits (PCCs) available. Finally, the total number of carbon credits generated (NCCG) of the regional case study was quantified.

\subsection{Regional Case Study}

To carry out this research, the Valencia Region in eastern Spain has been identified and chosen as a case study, since Valencia has an important forest area (1.2 million hectares, $57 \%$ of the total area) and well represents Mediterranean forestry [27]. The $72 \%$ of woodlands are dominated by Pinus halepensis Mill., while Quercus ilex L. represents the main species in only the $14 \%$ of this area [28]. Valencia has a population of about 5 million people that live on an area of more than 23 thousand $\mathrm{km}^{2}$. Most of its inhabitants live in coastal municipalities, where intensive agriculture and industry developed, as well as services and tourism. The interior of the region is very mountainous, dominated by an agroforestry landscape, but with very pronounced rural abandonment during the last five decades. Rural municipalities occupy $61.85 \%$ of the Valencian territory, while only contain $6.82 \%$ of the total population [28]. Additionally, between $18 \%$ and $24.8 \%$ of rural inhabitants are older than 65 , which has led to an ageing population. This situation has propitiated that many agricultural lands get evolved into forest without any type of management by the rural owners (see Figure 2) [29]. In fact, in last decade forest area has had an average increase of 3300 ha/year [28], mainly being converted into coniferous woodlands. Land ownership also affects forest management in Valencia Region. It is characterized by being 
mainly private, smallholder, and disaggregated. In Valencia, $55.2 \%$ of forest areas belong to private owners, $36.8 \%$ to public entities (mainly to municipalities), and $6.3 \%$ to unknown proprietors [28]. Moreover, more than half of the private lands have less than 1 ha. area and approximately one third of the forest area are located within agriculture and agroforestry parcels [28], which makes it more difficult to manage. Climate is the typical Mediterranean climate characterized by having mild winters, warm autumns, rainy springs, and dry and hot summers, in which forest fires abound. As for all Mediterranean regions, Valencia is classified as one of the most negatively affected by climate change in Europe [30].

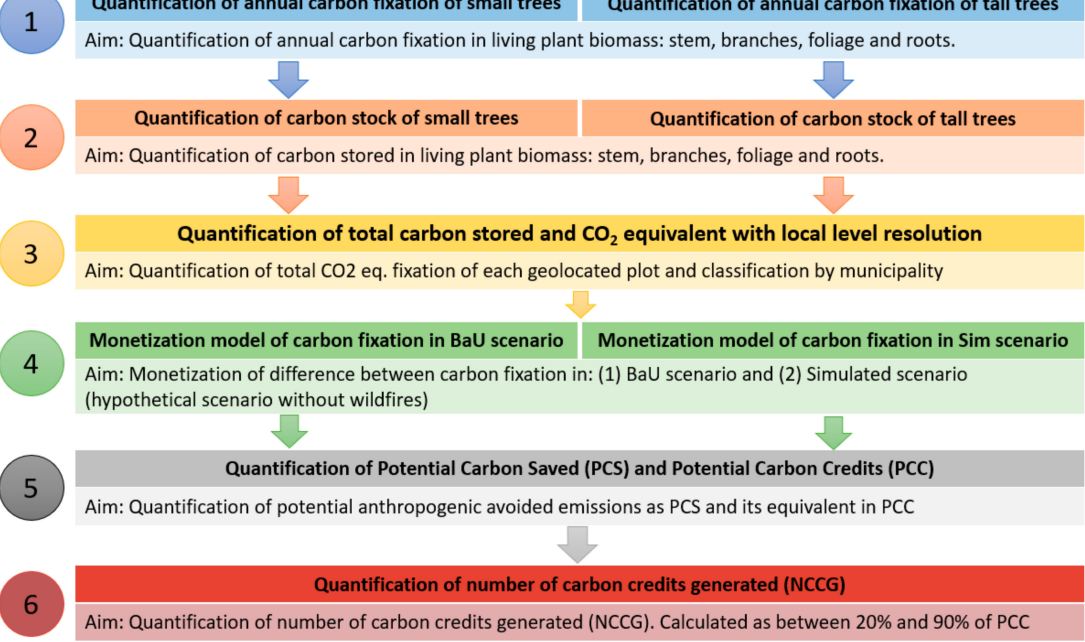

Figure 1. Diagram of the methodology steps.

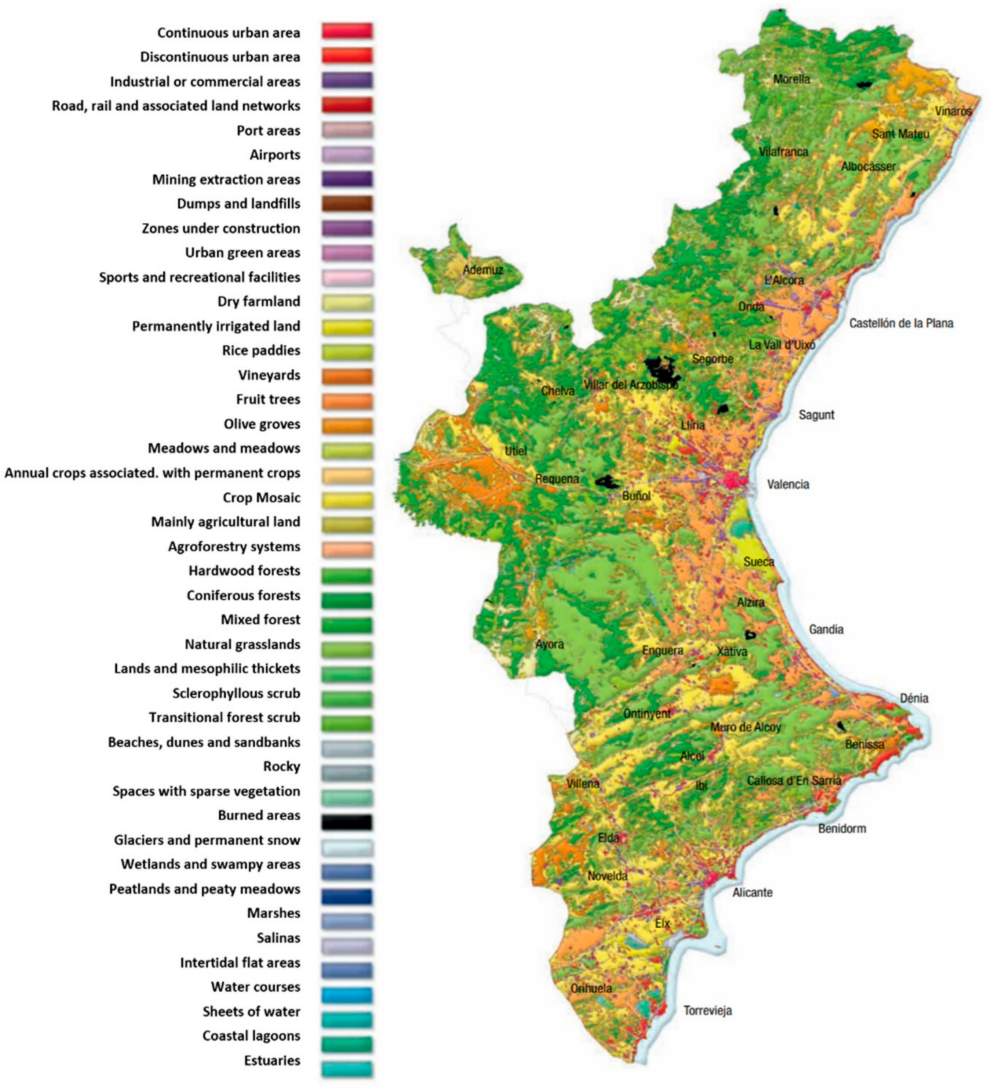

Figure 2. Land cover map of the region of Valencia (Spain) [31]. 


\subsection{Quantification of Carbon Fixation in Forest Biomass under Mediterranean Conditions}

The quantification of $\mathrm{CO}_{2}$ eq. sequestered in forestry in this regional case study has been focused on the carbon stored in living plant biomass: stem, branches, foliage, and roots. Thus, firstly annual growth in terms of dry weight of biomass has been calculated differentiating between small trees (diameter at breast high (DBH) $<7.5 \mathrm{~cm}$ ) and tall trees $(\mathrm{DBH}>7.5 \mathrm{~cm}$ ). The methodology described by Montero et al. [32] has been followed to quantify annual growth of small trees. To quantify the annual growth of tall trees, the methodology described by Lerma-Arce [33], used to calculate cumulative biomass existence, has been adapted to calculate the annual growth of biomass (in dry weight). Then, a carbon fraction of dry weight biomass of 0.5 (weight Carbon/weight dry biomass) as the mean value of different authors consulted [2,32,34-39] has been used. Finally, the stoichiometric relationship between carbon and $\mathrm{CO}_{2}$ is used to obtain the amount of $\mathrm{CO}_{2}$ equivalent $\left(\mathrm{CO}_{2}\right.$ eq.) that is fixed annually.

The data for the application of these methodologies were obtained from the National Forest Inventory database in Spain (IFN3) [40]. The IFN3 characterizes a number of stands that describe forest ecosystems present in each region, according to the species present, their respective occupations and their age stage (see Table 1). Then, the forest area of the region is divided into different geolocated plots. Each plot is characterized by the stand to which it belongs and its area. Thus, carbon fixation of small and tall trees classified by diametric classes has been quantified per plot.

Table 1. Stands defined to Valencia Region. Source: IFN3 [40].

\begin{tabular}{|c|c|c|c|c|}
\hline Stand & $\begin{array}{l}\text { Dominant } \\
\text { Species }\end{array}$ & Occupation (\%) & Stage & $\begin{array}{c}\text { Canopy Cover } \\
(\%)\end{array}$ \\
\hline 01 & Pinus halepensis & $\geq 70$ & Old growth & $70-100$ \\
\hline 02 & Pinus halepensis & $\geq 70$ & Old growth & $40-69$ \\
\hline 03 & Pinus halepensis & $\geq 70$ & Old growth & $20-39$ \\
\hline 04 & Pinus halepensis & $\geq 70$ & Young forest & $5-100$ \\
\hline 05 & $\begin{array}{l}\text { Pinus nigra and } P . \\
\text { pinaster or mixed } \\
\text { with Pinus } \\
\text { halepensis }\end{array}$ & $\geq 70 ; 30 \leq$ Sp. $<70$ & Old growth & $40-100$ \\
\hline 06 & $\begin{array}{l}\text { Pinus nigra and } P \text {. } \\
\text { pinaster or mixed } \\
\text { with Pinus } \\
\text { halepensis }\end{array}$ & $\geq 70 ; 30 \leq$ Sp. $<70$ & Old growth & $20-39$ \\
\hline 07 & $\begin{array}{l}\text { Quercus ilex or } \\
\text { mixed with Pinus } \\
\text { halepensis or } \\
\text { Ceratonia siliqua }\end{array}$ & $\geq 70 ; 30 \leq$ Sp. $<70$ & Old growth & $20-100$ \\
\hline 08 & $\begin{array}{l}\text { Quercus ilex or } \\
\text { mixed with } \\
\text { Pinus spp. }\end{array}$ & $\geq 70 ; 30 \leq$ Sp. $<70$ & Young forest & $5-100$ \\
\hline 09 & Juniperus thurifera & $\geq 70$ & $\begin{array}{l}\text { Old growth, } \\
\text { Young Forest }\end{array}$ & $\begin{array}{c}20-100 \\
5-100\end{array}$ \\
\hline 10 & $\begin{array}{c}\text { Riverside trees } \\
\text { (Populus spp., } \\
\text { Fraxinus spp.... ) }\end{array}$ & $\geq 70 ; 30 \leq$ Sp. $<70$ & All & $5-100$ \\
\hline 11 & Scrub & $\geq 70 ; 30 \leq$ Sp. $<70$ & Old growth & 5-19 \\
\hline
\end{tabular}

Table is originally cited from Tercer Inventario Forestal Nacional as per the Spanish Government. 


\subsubsection{Quantification of Carbon Fixation of Small Trees}

The quantification of the carbon fixed by the small trees $(\mathrm{DBH}<7.5 \mathrm{~cm})$ was obtained from Equation (1):

$$
\text { Carbon Fixation }_{s t}(t \mathrm{C} / \text { year })=\sum_{\text {plots }} A I D W s t_{k} \times N^{\circ} s t_{j} \times \text { Area }_{i} \times C F
$$

where:

AIDWst: Annual increment of dry weight of a small tree (DBH $<7.5 \mathrm{~cm})$, in tonnes per year

$\mathrm{N}^{\circ}$ st: Number of small trees per hectare

Area: Area of plot in hectares

CF: Carbon fraction of dry weight biomass $(0.5 \mathrm{t} \mathrm{C} / \mathrm{t}$ dry biomass $)$

$i$ : plot

$k$ : species

$j$ : stand

The annual increment of dry weight of small trees was obtained from the models developed by Montero et al. [32], which measure the average annual increment of dry weight of different species with $\mathrm{DBH}<7.5 \mathrm{~cm}$. The number of small trees per hectare were obtained from the characterization of the stand to which that plot belongs in IFN3 [40] (see Table 2). IFN3 also offers the area of each plot.

Table 2. Example of forest stands characterization in Valencia. Source: adapted from IFN3 [40].

\begin{tabular}{|c|c|c|c|c|}
\hline $\begin{array}{l}\text { Species or Group } \\
\text { of Species }\end{array}$ & $\begin{array}{c}\mathbf{N}^{\circ} \text { rt: Number of } \\
\text { Tall Trees Per } \\
\text { Hectare }\left(\mathbf{N}^{\circ} \mathrm{tt} / \mathrm{ha}\right)\end{array}$ & $\operatorname{VWB}\left(\mathrm{m}^{3}\right)$ & $\operatorname{AIVCrt}\left(\mathrm{m}^{3}\right)$ & $\begin{array}{l}\mathbf{N}^{\circ} \text { st: Number of } \\
\text { Small Trees Per } \\
\text { Hectare ( }{ }^{\circ} \text { st/ha) }\end{array}$ \\
\hline Pinus halepensis & 605.55 & 67.962 & 2.349 & 286.48 \\
\hline Pinus pinaster & 1.39 & 0.305 & 0.010 & 3.82 \\
\hline Pinus nigra & 0.07 & 0.015 & 0.000 & 0.00 \\
\hline Quercus ilex & 3.17 & 0.108 & 0.002 & 38.20 \\
\hline Juniperus thurifera & 1.27 & 0.021 & 0.001 & 138.78 \\
\hline Ceratonia siliqua & 2.80 & 0.212 & 0.002 & 5.09 \\
\hline $\begin{array}{c}\text { Riverside trees } \\
\text { (Populus spp., } \\
\text { Fraxinus spp.... ) }\end{array}$ & 0.03 & 0.071 & 0.001 & 4.46 \\
\hline $\begin{array}{c}\text { Other hardwood } \\
\text { trees }\end{array}$ & 2.23 & 0.075 & 0.001 & 12.73 \\
\hline Total & 616.51 & 68.773 & 2.366 & 489.56 \\
\hline
\end{tabular}

\subsubsection{Quantification of Carbon Fixation of Tall Trees}

The quantification of the carbon fixed by tall trees $(\mathrm{DBH}>7.5 \mathrm{~cm})$ was obtained from Equation (2):

$$
\text { Carbon Fixation }_{n s t}(t C / \text { year })=\sum_{\text {plots }} A I V C t t_{j, k} \times B D_{k} \div \% \text { stem }_{k} \times \text { Area }_{i} \times C F
$$

where:

AIVCtt: Annual increment of volume of the stem of tall trees, in $\mathrm{m}^{3} / \mathrm{ha}$.

$B D$ : Basic density

Area: Area of plot in hectares

\%stem: percentage of the stem weigh over the rest of the tree biomass (see Table 3).

$C F$ : Carbon fraction of dry weight biomass $(0.5 \mathrm{t} \mathrm{C} / \mathrm{t}$ dry biomass $)$

$i$ : plot 
$k$ : species

$j$ : stand

The AIVCtt by species was obtained from IFN3 [40]. The percentage of the stem weight over the rest of the tree biomass by species was obtained from the models of Montero et al. [32]. The area of each plot is also obtained from IFN3. Table 3 shows the relative value in dry weight of each part of the tree adapted from Montero et al. [32].

Table 3. Relative value that represents the dry weight of each part of the tree. Adapted from Montero et al. [32].

\begin{tabular}{|c|c|c|c|c|c|c|c|}
\hline \multicolumn{7}{|c|}{ Aerial Biomass } & \multirow{3}{*}{$\begin{array}{l}\text { Radical } \\
\text { Biomass }\end{array}$} \\
\hline \multirow{2}{*}{ Species } & \multirow{2}{*}{ Stem } & \multicolumn{3}{|c|}{ Branches } & \multirow{2}{*}{ Leaves } & \multirow{2}{*}{ Total } & \\
\hline & & $\mathrm{R}>7 \mathrm{~cm}$ & R $2-7 \mathrm{~cm}$ & $\mathrm{R}<2 \mathrm{~cm}$ & & & \\
\hline Pinus halepensis & $37 \%$ & $9.80 \%$ & $8.40 \%$ & $21.20 \%$ & $0 \%$ & $76.40 \%$ & $23.60 \%$ \\
\hline Pinus nigra & $51.10 \%$ & $5.40 \%$ & $8.00 \%$ & $15.90 \%$ & $0 \%$ & $80.40 \%$ & $19.60 \%$ \\
\hline Pinus pinaster & $61.9 \%$ & $0.9 \%$ & $4.1 \%$ & $10.9 \%$ & $0.0 \%$ & $77.9 \%$ & $22.1 \%$ \\
\hline Pinus pinea & $36.4 \%$ & $17.7 \%$ & $11.4 \%$ & $13.4 \%$ & $5.6 \%$ & $84.5 \%$ & $15.5 \%$ \\
\hline Pinus sylvestris & $56.1 \%$ & $2.5 \%$ & $7.0 \%$ & $7.4 \%$ & $5.6 \%$ & $78.6 \%$ & $21.4 \%$ \\
\hline $\begin{array}{c}\text { Populus } x \\
\text { euramericana }\end{array}$ & $48.9 \%$ & $6.4 \%$ & $6.4 \%$ & $6.1 \%$ & $2.3 \%$ & $76.0 \%$ & $24.0 \%$ \\
\hline Quercus ilex & $18.4 \%$ & $24.2 \%$ & $12.2 \%$ & $8.7 \%$ & $2.0 \%$ & $65.4 \%$ & $34.6 \%$ \\
\hline Quercus faginea & $25.1 \%$ & $24.7 \%$ & $9.9 \%$ & $5.5 \%$ & $3.2 \%$ & $68.4 \%$ & $31.6 \%$ \\
\hline Quercus suber & $32.4 \%$ & $30.8 \%$ & $10.5 \%$ & $2.4 \%$ & $1.4 \%$ & $77.5 \%$ & $22.5 \%$ \\
\hline Juniperus thurifera & $35.8 \%$ & $7.8 \%$ & $14.6 \%$ & $9.3 \%$ & $8.5 \%$ & $76.1 \%$ & $23.9 \%$ \\
\hline Juniperus oxycedrus & - & - & - & - & - & $21.8 \%$ & $78.2 \%$ \\
\hline Ceratonia siliqua & $17.7 \%$ & $13.1 \%$ & $7.4 \%$ & $7.7 \%$ & $5.3 \%$ & $51.2 \%$ & $48.8 \%$ \\
\hline Olea europaea & $19.6 \%$ & $25.0 \%$ & $13.3 \%$ & $9.3 \%$ & $1.3 \%$ & $68.6 \%$ & $31.4 \%$ \\
\hline Fraxinus excelsior & $24.4 \%$ & $11.7 \%$ & $11.8 \%$ & $9.9 \%$ & $0.0 \%$ & $57.8 \%$ & $42.2 \%$ \\
\hline
\end{tabular}

\subsection{Quantification of Total Carbon Fixed and $\mathrm{CO}_{2}$ Equivalent with Local Level Resolution}

The quantification of the total carbon fixed by living plant biomass of forestry was obtained from Equation (3):

$$
\text { Carbon Fixation }_{\text {total }}(t \mathrm{C} / \text { year })=\text { Carbon Fixation }_{s t}+\text { Carbon Fixation }_{t t}
$$

Then, Equation (4) shows how many tons of $\mathrm{CO}_{2}$ eq. are obtained from the amount of carbon calculated in Equation (3). Note that it must be multiplied by the relationship between the weight of the $\mathrm{CO}_{2}$ molecule and the weight of the $\mathrm{C}$ atom (44/12):

$$
\mathrm{CO} 2 \text { eq. Fixation }(t / \text { year })=\text { Carbon Fixation } \times \frac{44}{12}
$$

The total $\mathrm{CO}_{2}$ eq. fixation of each geolocated plot is intersected with the local administrative layer of the Geographic Information System (GIS), which includes all of the 562 municipalities of the region. With this geographical segmentation, the developed model is able to calculate the total $\mathrm{CO}_{2}$ eq. fixation of local forests with high spatial resolution. 


\subsection{Monetization of Carbon Fixation in Mediterranean Forests}

To monetize the carbon fixation of the Mediterranean forest, an innovative methodology has been developed. This aims to analyze the potential to generate carbon credits as anthropogenic avoided emissions due to reduced wildfire risk compared with a $\mathrm{BaU}$ scenario. To achieve this, firstly a literature review to obtain carbon credit prices based on existing carbon markets has been carried out. Several forestry based carbon markets [41-43] have been analyzed and the carbon credit price has been calculated based on the price of these markets.

Up to today, the calculation of carbon credits generated by forestry has been based on the difference of the theoretical growth scenario without any type of silvicultural measure $(\mathrm{BaU})$ with respect to a scenario affected by different measures (mainly afforestation and reforestation) [41-43]. Increasing the number of trees is an adequate measure for forests where the species have an important economic value and therefore product-oriented harvesting is guaranteed, e.g., in central and northern European countries [44]. However, in most southern Mediterranean countries, wood has a normally low economic value and consequently low harvesting rates [45]. This low level of management implies the accumulation of combustible biomass, which directly influences a higher vulnerability to fire in the Mediterranean forest ecosystems, especially in times of severe drought [46]. Realistically, the reduction of wildfire risk and magnitude would be a highly effective measure to mitigate climate change, since the emission of a large amount of GHG would be avoided [47]. For this reason, the developed methodology calculates the BaU scenario taking into account the extent of wildfires in the region over the last 10 years. This scenario is compared with a simulated case without wildfires. The range between the carbon stocks stored in both scenarios represents the number of potential carbon credits that could be generated as anthropogenic avoided emissions in a 10-year period. This period has been chosen because it is the period of time usually used in the forest management plans [48] and it allows excessive influence of anomalous events to be avoided depending on the moment that the methodology would be applied. For example, in the case of an extraordinary wildfire event in the previous year and taking only this year as BaU scenario, results of carbon credits available would be unrealistic and highly influenced by this event.

2.4.1. Model for Monetization of Carbon Fixation in a Business as Usual (BaU) Scenario

Equation (5) exposes the developed model for monetization of carbon fixation in a BaU scenario.

$$
f(x)=\frac{\left(C_{t 0}-C_{t m}\right)}{\left(t_{0}-t_{m}\right)} \times\left(x-t_{0}\right)+C_{t 0}
$$

where:

$f(x)$ : Carbon stored determined by the year $(x)$ in the BaU scenario.

$t_{0}$ : Base year (first year of the period)

$t_{m}$ : Any year of the 10-year period

$C_{t 0}$ : Carbon stock in the base year. Calculated following the methodologies described by Montero et al. [32] and Lerma-Arce [33]. $C_{t 0}$ is calculated by Equation (6).

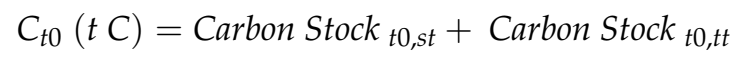

where:

Carbon Stock ${ }_{t 0, s t}$ : Carbon stock in the base year of small trees. Calculated by the Equation (7)

Carbon Stock ${ }_{t 0, t t}$ : Carbon stock in the base year of tall trees. Calculated by the Equation (8).

$$
\text { Carbon Stock } \text { st }(t C)=\sum_{\text {plots }} N^{\circ} s t_{j} \times \text { Area }_{i} \times M C \times \pi \times R^{2} \times h \times C F
$$

where:

$N^{\circ} s t$ : Number of small trees per hectare 
Area: Area of plot in hectares

$C F$ : Carbon fraction of dry weight biomass $(0.5 \mathrm{t} \mathrm{C} / \mathrm{t}$ dry biomass $)$

MC: Morphic Coefficient

$R$ : Radius in meters ( $0.025 \mathrm{~m}$ based on Montero et al. [32])

$h$ : Height in meters (1.6 m based on Montero et al. [32])

$i$ : plot

$j$ : stand

$$
\text { Carbon Stock } k_{t t}(t C)=\sum_{\text {plots }} V W B_{j, k} \times B D_{k} \div \% \text { stem }_{k} \times \text { Area }_{i} \times C F
$$

where:

$V W B$ : Volume with bark of stem in cubic meters (see Table 2)

$B D$ : Basic density

Area: Area of plot in hectares

$\%$ stem: percentage of the stem weigh regarding the rest of the tree biomass (see Table 3 )

$C F$ : Carbon fraction of dry weight biomass $(0.5 \mathrm{t} \mathrm{C} / \mathrm{t}$ dry biomass $)$

$i$ : plot

$k$ : species

$j$ : stand

$C_{t m}$ : Carbon stock in the year m, obtained from Equation (9).

$$
C_{t m}=C_{t(m-1)}-\overline{C \text { burned }}-\overline{C p}-\overline{C b}+\text { Carbon fixation }_{\text {total }}
$$

where:

$C_{t(m-1)}$ : Carbon stock in the year before $\mathrm{m}$

$\overline{\mathrm{C} p}$ : Average of carbon stock extracted from forest to products manufacturing (see Table 4)

$\overline{\mathrm{Cb}}$ : Average of carbon stock extracted from forest to bioenergy (see Table 4)

C burned: Average of carbon losses by wildfires calculated as Equation (10).

$$
\overline{\text { C burned }}=\frac{C_{t 0}}{\text { For.Area }} * \overline{B A} * \overline{\% B C}
$$

where:

For.Area: Forestry area of total region in hectares (see Table 4)

$\overline{B A}$ : Average of burned area over the 10 years in hectares (see Table 4)

$\overline{\% B C}$ : Average of biomass consumed during wildfire due to severity (see Table 4).

$C_{t 0}$ : Carbon stock in the base year.

Table 4. Value used in variables to the study case of Valencia.

\begin{tabular}{ccc}
\hline Variable & Value & Reference \\
\hline $\begin{array}{c}\text { Average of carbon stock } \\
\text { extracted from forest to } \\
\text { products manufacturing }\end{array}$ & $417,273 \mathrm{t} \mathrm{C/year}$ & {$[49]$} \\
\hline $\begin{array}{c}\text { Average of carbon stock } \\
\text { extracted from forest } \\
\text { to bioenergy }\end{array}$ & $71,300 \mathrm{t} \mathrm{C/year}$ & {$[49]$} \\
\hline $\begin{array}{c}\text { Forestry area of total region } \\
\text { in hectares }\end{array}$ & $1,200,194$ ha & {$[40]$} \\
\hline $\begin{array}{c}\text { Average of burned area of the } \\
10 \text { years in hectares }\end{array}$ & 9732 ha/year & [50] \\
\hline $\begin{array}{c}\text { Average of biomass consumed } \\
\text { during wildfire due } \\
\text { to severity }\end{array}$ & $72.6 \%$ & $\begin{array}{c}\text { Calculated in REMAS Interreg } \\
\text { SUDOE project currently in } \\
\text { progress [51] }\end{array}$ \\
\hline
\end{tabular}




\subsubsection{Model for Monetization of Carbon Fixation in a Simulated Scenario}

Equation (11) exposes the developed model for monetization of carbon fixation in a simulated scenario, which represent a hypothetical scenario without wildfires.

$$
g(x)=\frac{\left(C_{t 0}-\operatorname{CSim}_{t m}\right)}{\left(t_{0}-t_{m}\right)} \times\left(x-t_{0}\right)+C_{t 0}
$$

where:

$g(x)$ : carbon stored determined by the year $(x)$ in the simulated scenario.

$t_{0}$ : Base year (first year of the period)

$t_{m}$ : Any year of the 10-year period

$m$ : Year

$C_{t 0}$ : Carbon stock in the base year.

$\mathrm{CSim}_{t m}$ : Carbon stock in the year $\mathrm{m}$ in a scenario simulated without wildfires obtained from Equation (12).

$$
\operatorname{CSim}_{t m}=\operatorname{CSim}_{t(m-1)}-\overline{C p}-\overline{C b}+\text { Carbon fixation }_{\text {total }}
$$

where:

$\operatorname{CSim}_{t(m-1)}$ : Carbon stock in the year before $\mathrm{m}$ in the simulated scenario

$\overline{C p}$ : Average of carbon stock extracted from forest to products manufacturing (see Table 4).

$\overline{C b}$ : Average of carbon stock extracted from forest to bioenergy (see Table 4).

Thus, the total potential carbon saved (PCS) is calculated with Equation (13), being the area between the two scenarios functions $f(x)$ and $g(x)$.

$$
\text { Potential Carbon Saved }=\int_{\text {year } 0}^{\text {year } 9}[g(x)-f(x)] d x
$$

Therefore, the number of potential carbon credits (PCCs) corresponding with potential anthropogenic avoided emissions are obtained from Equation (14):

$$
\text { Potential Carbon Credits (PCC) }=\text { Potential Carbon Saved } \times \frac{44}{12}
$$

Finally, the number of carbon credits generated (NCCG) will be between $20 \%$ and $90 \%$ of the amount of Potential Carbon Credits (PCC) (in $\mathrm{t} \mathrm{CO}_{2}$ eq.) in the simulated 10-year period. A maximum of $90 \%$ is used because the fire risk cannot be completely reduced [52]. The minimum $20 \%$ of the PCC available is due to fuel biomass reduction by fire prevention measures and consequent forest resilience improvement. Therefore, the NCCG will be defined by Equation (15):

$$
20 \% \text { PCC } \leq \text { NCCG } \leq 90 \% \text { PCC }
$$

\subsection{Comparison between Carbon Fixation with Total GHG Emissions}

The amount of annual $\mathrm{CO}_{2}$ fixation has to be compared with the total amount of GHG emissions (direct and diffuse) in the case study region. It is important to differentiate because direct GHG emissions have their own mandatory carbon market (EU ETS), but diffuse GHG emissions could be a potential voluntary carbon market at the regional level. So, on the one side, direct GHG emissions of EU ETS industries have been quantified by digitalizing the annual GHG emissions notifications of the companies obligated to report their GHG emissions based on the 2003/87/EC Directive [53]. These notifications were obtained from OECC [54]. Conversely, diffuse GHG emissions have been calculated with national GHG emissions inventory based on a per inhabitants' ratio [55]. 


\subsection{Evaluation of the Potential of Mediterranean Forestry for Offsetting GHG Emissions}

Finally, the potential of Mediterranean forestry for offsetting GHG emissions through the monetization of anthropogenic-avoided emissions has been evaluated with the previous expressed models.

\section{Results and Discussion}

\subsection{Total Carbon Fixation by Forest Biomass}

The results of the application of the methodologies described for the Valencia region show a total amount of annual fixation of 3.16 million $\mathrm{t}$ of $\mathrm{CO}_{2}$ eq. distributed at the local level (see Figure 3). This carbon fixation is distributed in 1.52 million $t$ of $\mathrm{CO}_{2}$ eq. produced by small trees and 1.64 million $\mathrm{t}$ of $\mathrm{CO}_{2}$ eq. produced by tall trees.

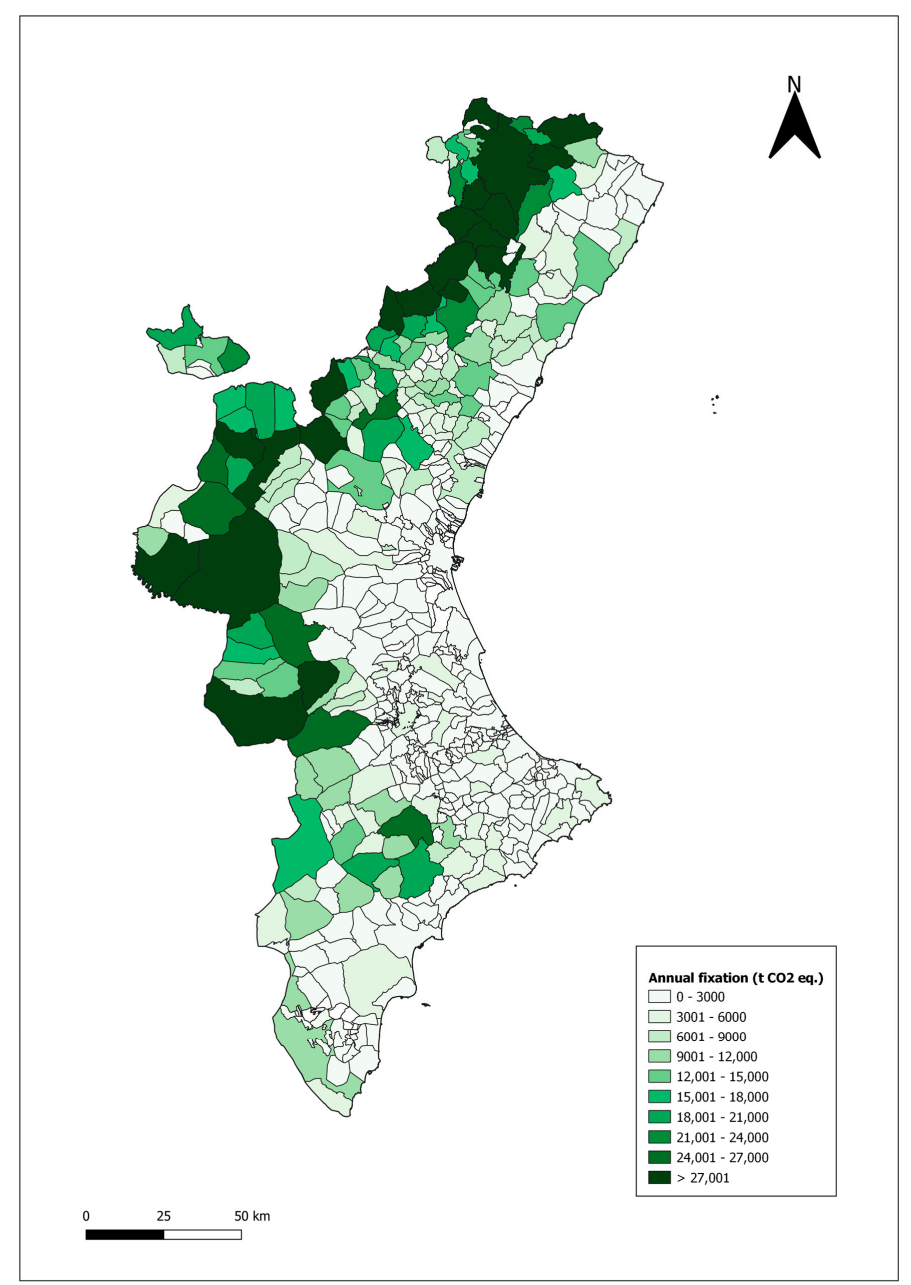

Figure 3. Spatial distribution of annual $\mathrm{CO}_{2}$ eq. fixation with local level resolution in Valencia region (Spain).

$\mathrm{CO}_{2}$ eq. fixation has been calculated in 473 municipalities with forests, from a total of 542 municipalities in the region. This represents $87.27 \%$ of total municipalities. Table 5 shows the most $\mathrm{CO}_{2}$ eq. fixation municipalities in the region. These 19 municipalities represent the $\mathrm{CO}_{2}$ eq. fixation of $40 \%$ of total fixation. Actually, the higher $\mathrm{CO}_{2}$ fixation is produced in rural municipalities in the western mountainous areas (see Figure 3), which are less populated. For this reason, the monetization of the forest services as $\mathrm{CO}_{2}$ fixation could be a very good option to mitigate and to adapt to climate change and to reduce rural depopulation. 
Table 5. Municipalities of Valencia (Spain) with the highest $\mathrm{CO}_{2}$ eq. fixation.

\begin{tabular}{|c|c|c|c|}
\hline Municipality Name & $\begin{array}{l}\text { Annual } \mathrm{CO}_{2} \text { eq. } \\
\text { Fixation }\left(\mathrm{t} \mathrm{CO}_{2}\right. \\
\text { eq./Year) }\end{array}$ & $\begin{array}{c}\text { Relative Value } \\
\text { Regarding Total } \mathrm{CO}_{2} \\
\text { eq. Fixation }(\%)\end{array}$ & $\begin{array}{l}\text { Cumulative Relative } \\
\text { Value of } \mathrm{CO}_{2} \text { eq. (\%) }\end{array}$ \\
\hline Morella & 269,910 & 8.53 & 8.53 \\
\hline Requena & 111,459 & 3.52 & 12.06 \\
\hline Pobla de Benifassà & 93,688 & 2.96 & 15.02 \\
\hline $\begin{array}{l}\text { Vistabella del } \\
\text { Maestrat }\end{array}$ & 93,421 & 2.95 & 17.97 \\
\hline Vallibona & 78,851 & 2.49 & 20.47 \\
\hline El Toro & 72,732 & 2.30 & 22.77 \\
\hline Ares del Maestrat & 66,485 & 2.10 & 24.87 \\
\hline Ayora & 60,373 & 1.91 & 26.78 \\
\hline Villahermosa del Río & 56,822 & 1.80 & 28.57 \\
\hline Vilafranca & 44,387 & 1.40 & 29.98 \\
\hline Venta del Moro & 43,399 & 1.37 & 31.35 \\
\hline Castellfort & 40,518 & 1.28 & 32.63 \\
\hline Cortes de Arenoso & 40,414 & 1.28 & 33.91 \\
\hline Zorita del Maestrazgo & 37,056 & 1.17 & 35.08 \\
\hline Chelva & 36,819 & 1.16 & 36.24 \\
\hline Culla & 36,259 & 1.15 & 37.39 \\
\hline Benassal & 30,870 & 0.98 & 38.37 \\
\hline Andilla & 30,498 & 0.96 & 39.33 \\
\hline Tuéjar & 28,774 & 0.91 & 40.24 \\
\hline
\end{tabular}

\subsection{Value of Carbon Fixed by Mediterranean Forests}

The average carbon credit price calculated for year 2020 based on the forest carbon markets analyzed [41-43] is $16 € / \mathrm{t} \mathrm{CO}_{2}$ eq. Thus, this price has been used to estimate the monetization of GHG emissions balance of the region with local level resolution.

The results of carbon stored in a BaU and in a simulated scenario for the 10-year period analyzed in the pilot region can be seen in Table 6.

Table 6. Results of carbon stored quantification in business as usual (BaU) and simulated scenarios, 2006 to 2015.

\begin{tabular}{|c|c|c|c|c|c|}
\hline \multicolumn{3}{|c|}{ BaU Scenario } & \multicolumn{3}{|c|}{ Simulated Scenario } \\
\hline 2006 & $\mathrm{C}_{\mathrm{t} 0}(\mathrm{t} \mathrm{C})$ & $18,877,336$ & 2006 & $\mathrm{C}_{\mathrm{t} 0}(\mathrm{t} \mathrm{C})$ & $18,877,336$ \\
\hline 2007 & \multirow{9}{*}{$\mathrm{C}_{\mathrm{tm}}(\mathrm{t} \mathrm{C})$} & $19,123,160$ & 2007 & \multirow{9}{*}{$\mathrm{CSim}_{\mathrm{tm}}(\mathrm{t} \mathrm{C})$} & $19,234,277$ \\
\hline 2008 & & $19,368,985$ & 2008 & & $19,591,219$ \\
\hline 2009 & & $19,614,810$ & 2009 & & $19,948,161$ \\
\hline 2010 & & $19,860,634$ & 2010 & & $20,305,103$ \\
\hline 2011 & & $20,106,459$ & 2011 & & $20,662,045$ \\
\hline 2012 & & $20,352,284$ & 2012 & & $21,018,986$ \\
\hline 2013 & & $20,598,108$ & 2013 & & $21,375,928$ \\
\hline 2014 & & $20,843,933$ & 2014 & & $21,732,870$ \\
\hline 2015 & & $21,089,758$ & 2015 & & $22,089,812$ \\
\hline
\end{tabular}


Thus, the total Potential Carbon Saved (PCS) is 4.5 million $t$ of $C$, being the area between the two scenarios functions $f(x)$ and $g(x)$ (see Figure 4).

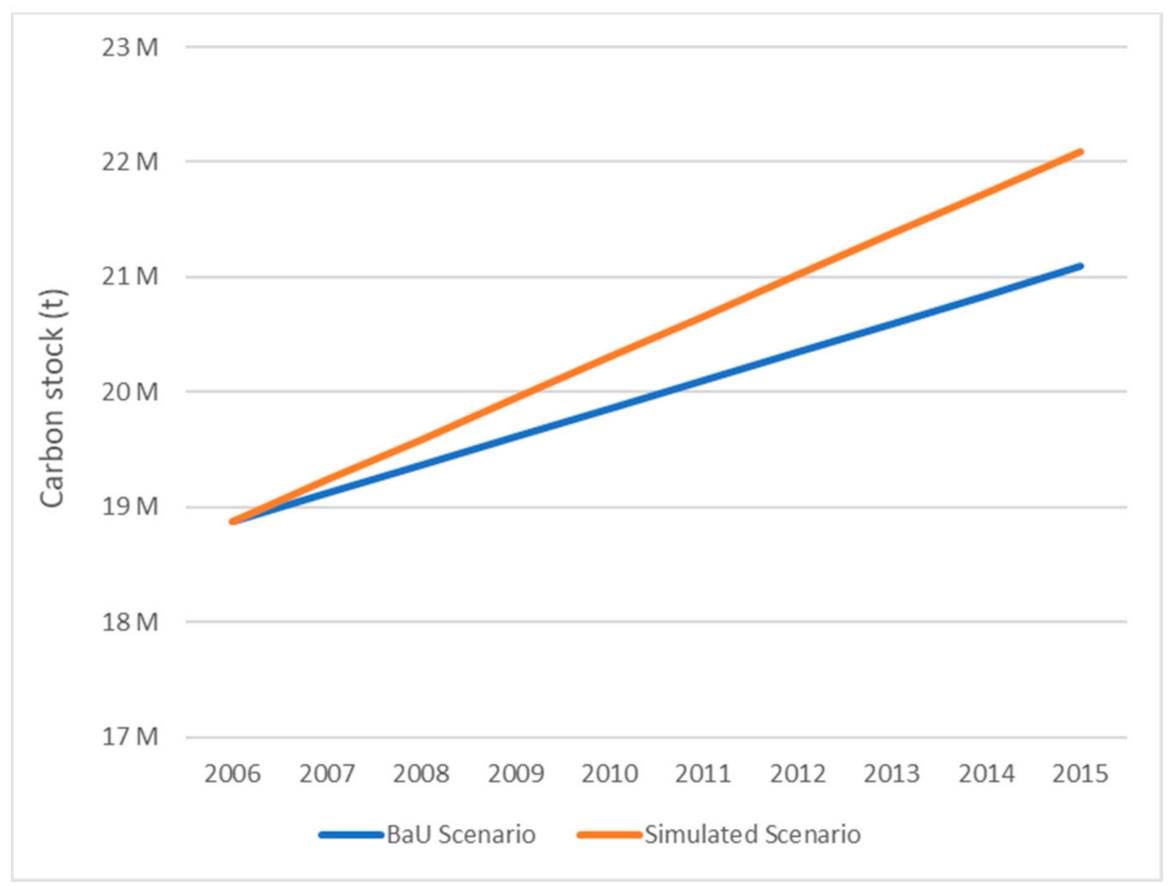

Figure 4. Graphical representation of $f(x)$ and $g(x)$ functions of BaU and simulated scenarios respectively.

Then, the number of potential carbon credits (PCC) was 16,500,898, which correspond to potential anthropogenic avoided emissions in terms of $\mathrm{t} \mathrm{CO}_{2}$ eq. Therefore, the number of carbon credits generated (NCCG) will be between 3,300,179 and 14,850,808 (equivalent to $\mathrm{CO}_{2}$ eq.) in the simulated 10-year period in the region. Consequently, the monetization of the calculated NCCG in the region based on the carbon price of forestry carbon markets analyzed was between 55.5 and 250 million $€$.

The model developed is easy to apply and offers results from a conservative point of view, so as not to overestimate the NCCG. The fact that it is easy to apply creates the possibility of using it as a system of measurement, reporting, and verification (MRV) in systems such as REDD + in those countries that, due to a low degree of deforestation, the cost of MRV is greater than the economic compensation of REDD + such as indicates Köhl et al. [26]. Despite these advantages, the model developed has some drawbacks that should be improved in future work. Some of these drawbacks are: (a) that the NCCG range is very wide; (b) soil carbon and detritus are not quantified; and (c) the model does not consider other carbon losses such as that caused by pests or other extreme weather conditions.

\subsection{Carbon Fixation in Relation to Total GHG Emissions}

The quantification of total gross GHG emissions in Valencia was 35.5 million $\mathrm{t} \mathrm{CO}_{2}$ eq. divided between direct and diffuse GHG emissions. The highest emitter sector was "Energy" with around 75\%, followed by "Industrial processes and product use" and "Agriculture" with 10\% each, and "Waste" with $5 \%$.

Direct GHG emissions from 178 EU ETS facilities in the region emit 8.9 million $t$ of $\mathrm{CO}_{2}$ eq. [54]. The main contributor is the ceramic sector, with $33 \%$ of the total direct emissions followed by the clinker sector with $21 \%$ and electricity generation with $18 \%$.

Diffuse GHG emissions are estimated as 26,622,550 $\mathrm{tCO}_{2}$ eq. across every municipality in the region. 
Therefore, the annual $\mathrm{CO}_{2}$ fixation by living biomass in forests compensate $9 \%$ of total gross GHG emissions and 15\% of diffuse emissions that have no compensation carbon market today.

\subsection{Potential of Mediterranean Forestry for Offsetting GHG Emissions}

The number of carbon credits generated (NCCG) calculated by the application of the methodology developed for the regional case of Valencia, would allow compensation of between 330,018 and 1,485,080 t $\mathrm{CO}_{2}$ per year. This would suppose a compensation potential between 1.2 and $5.6 \%$ of total diffuse GHG emissions.

Regional compensation of GHG emissions would produce immense positive benefits for society and the environment at local and regional levels: promoting actions maximizing forest cover on soils with marginal agricultural potential while concurrently increasing livelihoods and mitigating climate change, as demonstrated by Tong et al. [56]; creation of jobs linked to rural activities (rural development); minimizing natural disaster risks; conservation of biodiversity and natural habitats; revaluation of the territory and its resources; and promotion of low-carbon value chains (bioeconomy), in summary, improving the resilience and sustainability of socio-ecological systems [57].

Furthermore, although in a local carbon market there may be different stakeholders with diverse interests and different goals, a win-win solution is possible and beneficial for society [58]. Finally, the implementation of this model in other regions requires the availability of data inputs. Data sources have to provide information regarding forest characterization (such as occupied area), annual growth in living plant biomass, forestry treatments or actions (such as afforestation, reforestation, plantations, and harvesting) and at least 10 years of wildfire historical data. Additionally, assumptions considered in Section 2, such as the average of biomass consumed during wildfire due to severity, must be satisfied.

\section{Conclusions}

A quantification of $\mathrm{CO}_{2}$ fixation by living plant biomass within the forestry sector has been undertaken with high spatial resolution in a representative Mediterranean region with a clear lack of forest management (Valencia in Spain).

The methodology developed permitted monetization of $\mathrm{CO}_{2}$ fixation by forests with a new approach adapted to Mediterranean conditions, which takes into account the anthropogenic avoided emissions by sustainable forest management to actively prevent wildfire. In this way, a simulated scenario with forest management has been used to calculate the generation of carbon credits of avoided $\mathrm{CO}_{2}$ eq. emissions and to compare with a business as usual scenario. In addition, a literature review of the existing forest-based carbon markets has been carried out to estimate an average carbon credit price equivalent to one ton of $\mathrm{CO}_{2}$ eq.

The application of this methodology to the study case of the Valencia region has allowed a total monetization of between 55.5 and 250 million $€$, corresponding to 16.5 million of potential carbon credits generated equivalent to anthropogenic avoided emissions over

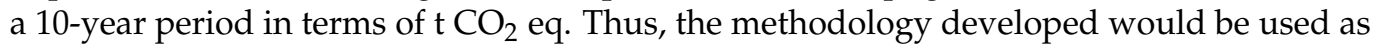
a system of measurement, reporting and verification (MRV) in systems such as REDD + in those countries that, due to a low degree of deforestation, the cost of MRV is greater than the economic compensation of REDD + system.

Finally, the comparison of carbon credits generated with total GHG emissions has highlighted the potential for offsetting between 1.2\% and 5.6\% of diffuse GHG per year (emissions without regulated carbon market) at the regional level. As future work, a quantification improvement of diffuse GHG emissions at the local level is necessary to enable the establishment of a voluntary carbon market in Mediterranean forest regions. On the other hand, the fixation produced by the soil and plant detritus should be added to the quantification of the carbon fixation of the forest land. Finally, more efficient silvicultural measures to enhance carbon sequestration and reduce wildfire risk should be studied and 
quantified in order to reduce the uncertainty range of the nnnumber of carbon credits generated (NCCG) with respect to the potential carbon credits (PCC) calculated.

Author Contributions: E.L.-S. and J.-V.O.-V. conceived of the presented research idea. E.L.-S., J.-V.O.V., V.L.-A., C.Y.-H. and L.G.L.-Z. developed the methodology and data curation. E.L.-S. and C.Y.-H. performed the data computations. V.L.-A. and J.-V.O.-V. verified the analytical methods. J.-V.O.-V. and L.G.L.-Z. encouraged E.L.-S. to apply the methodology to the studied area. All authors discussed the results and contributed to the final manuscript. All authors have read and agreed to the published version of the manuscript.

Funding: This research was funded by EIT Climate KIC in the frame of the ValVolCar project and by Interreg SUDOE REMAS project (SOE3/P4/E0954), project co-financed by the Interreg Sudoe Program through the European Regional Development Fund (ERDF).

Institutional Review Board Statement: Not applicable.

Informed Consent Statement: Not applicable.

Acknowledgments: We thank our colleagues from the Registry of Carbon Footprint, Compensation and $\mathrm{CO}_{2}$ Absorption Projects of the Ministry for Ecological Transition and Demographic Challenge of the Vice-presidency of the Government of Spain, who provided insight and expertise that greatly assisted the research.

Conflicts of Interest: The authors declare no conflict of interest. The funders had no role in the design of the study; in the collection, analyses, or interpretation of data; in the writing of the manuscript, or in the decision to publish the results.

\section{References}

1. Intergovernmental Panel on Climate Change (IPCC). Summary for Policymakers Climate Change 2001: Mitigation. A Report of Working Group III of the Intergovernmental Panel on Climate Change. Available online: https://www.ipcc.ch/site/assets/ uploads/2018/07/wg2TARsummaries.pdf (accessed on 7 April 2021).

2. Intergovernmental Panel on Climate Change (IPCC) Guidelines for National Greenhouse Gas Inventories. Task Force on National Greenhouse Gas Inventories (TFI), 2006. Available online: https://www.ipcc-nggip.iges.or.jp/public/2006gl/ (accessed on 7 April 2021).

3. Vine, E.; Sathaye, J.; Makundi, W. Guidelines for the Monitoring, Evaluation, Reporting, Verification and Certification of Forestry Projects for Climate Change Mitigation, LBNL-41543, Ernest Orlando Lawrence Berkeley National Laboratory; Environmental Energy Technologies Division: Berkeley, CA, USA, 1999; p. 146.

4. IEA Bioenergy. Greenhouse Gas Balances of Biomass: Answers to Ten Frequently Asked Questions about Bioenergy, Carbon Sinks and Their Role in Global Climate Change. 2001. Available online: https:/ /www.ieabioenergy.com/wp-content/uploads / 2013/10/13_task38faq.pdf (accessed on 7 April 2021).

5. Prato, T. Conceptual Framework for Assessing the Sustainability of Forest Fuel Reduction Treatments and Their Adaptation to Climate Change. Sustainability 2015, 7, 3571-3591. [CrossRef]

6. Wang, L.; Cui, Z.; Kuuluvainen, J.; Sun, Y. Does Forest Industries in China become Cleaner? A Prospective of Embodied Carbon Emission. Emission. Sustainability 2021, 13, 2306. [CrossRef]

7. Marques, S.; Marto, M.; Bushenkov, V.; McDill, M.; Borges, J.G. AddressingWildfire Risk in Forest Management Planning with Multiple Criteria Decision Making Methods. Sustainability 2017, 9, 298. [CrossRef]

8. Canadell, J.G.; Raupach, M.R. Managing forests for climate change mitigation. Science 2008, 320, 1456-1457. [CrossRef] [PubMed]

9. Streck, C.; Scholz, S.M. The role of forests in global climate change: Whence we come and where we go. Int. Aff. 2006, 82, 861-879. [CrossRef]

10. Binkley, C.S.; Brand, D.; Harkin, Z.; Bull, G.; Ravindranath, N.H.; Obersteiner, M.; Nilsson, S.; Yamagata, Y.; Krott, M. Carbon sink by the forest sector-options and needs for implementation. For. Policy Econ. 2002, 4, 65-77. [CrossRef]

11. Vigna, I.; Besana, A.; Comino, E.; Pezzoli, A. Application of the Socio-Ecological System Framework to Forest Fire Risk Management: A Systematic Literature Review. Sustainability 2021, 13, 2121. [CrossRef]

12. Moriondo, M.; Good, P.; Durão, R.; Bindi, M.; Giannakopoulos, C.; Corte-Real, J. Potential impact of climate change on fire risk in the Mediterranean area. Clim. Res. 2006, 31, 85-95. [CrossRef]

13. Joint Research Centre (JRC). Forest fires in Europe 2009, Joint Research Centre Scientific and Technical Reports; Report No. 10; Publication office of the European Union: Luxemburg, 2009.

14. Marchi, M.; Chianucci, F.; Ferrara, C.; Pontuale, G.; Pontuale, E.; Mavrakis, A.; Morrow, N.; Rossi, F.; Salvati, L. Sustainable Land-Use, Wildfires, and Evolving Local Contexts in a Mediterranean Country, 2000-2015. Sustainability 2018, 10, 3911. [CrossRef] 
15. Peters-Stanley, M.; Hamilton, K.; Yin, D. Leveraging the Landscape: State of the Forest Carbon Markets 2012. Ecosystem Marketplace. 2012. Available online: https://www.forest-trends.org/wp-content/uploads/imported/sofcm-final_11-7-12-pdf.pdf (accessed on 7 April 2021).

16. Kollmuss, A.; Zink, H.; Polycarp, C. Making Sense of the Voluntary Carbon Market: A Comparison of Carbon Offset Standards. Wwf Ger. 2008. Available online: https://mediamanager.sei.org/documents/Publications/SEI-Report-WWFComparisonCarbonOffset-08.pdf (accessed on 7 April 2021).

17. Ulucak, R.; Yücel, A.G.; Koçak, E. The Process of Sustainability: From Past to Present. In Environmental Kuznets Curve (EKC); Elsevier: Amsterdam, The Netherlands, 2019; Chapter 5; pp. 37-53, ISBN 9780128167977. [CrossRef]

18. FAO. Natural Resources Management and Environment Department Food and Agriculture Organization of the United Nations (FAO). Carbon Finance Possibilities for Agriculture, Forestry and Other Land Use Projects in a Smallholder Context. Rome. 2010. Available online: http://www.fao.org/3/i1632e/i1632e.pdf (accessed on 7 April 2021).

19. European Commission. EU ETS Handbook. European Union, Emission Trading System Handbook. 2015. Available online: https:/ / ec.europa.eu/clima/sites/clima/files/docs/ets_handbook_en.pdf (accessed on 7 April 2021).

20. Hamilton, K.; Bayon, R.; Turner, G.; Higgins, D. State of the Voluntary Carbon Markets 2007: Picking Up Steam. EcoSystem Marketplace and New Carbon Finance. Available online: http://ecosystemmarketplace.com/documents/acrobat/ StateoftheVoluntaryCarbonMarket17July.pdf (accessed on 7 April 2021).

21. Oficina Española Cambio Climático (OECC). Información Sobre la Sección de Proyectos de Absorción de Dióxido de Carbono. Registro de Huella de Carbono, Compensación y Proyectos de Absorción de Dióxido de Carbono; Oficina Española Cambio Climático: Madrid, Spain, 2019.

22. McKenzie, D.; Gedalof, Z.; Peterson, D.L.; Mote, P. Climatic change, wildfire, and conservation. Conserv. Biol. 2004, 18, 890-902. [CrossRef]

23. Stephens, S.L. Forest fire causes and extent on United States Forest Service lands. Int. J. Wildland Fire 2005, 14, 213-222. [CrossRef]

24. Westerling, A.L.; Hidalgo, H.G.; Cayan, D.R.; Swetnam, T.W. Warming and earlier spring increase western U.S. forest wildfire activity. Science 2006, 313, 940-943. [CrossRef]

25. Miller, J.D.; Safford, H.D.; Crimmins, M.; Thode, A.E. Quantitative evidence for increasing forest fire severity in the Sierra Nevada and southern Cascade Mountains, California and Nevada, USA. Ecosystems 2009, 12, 16-32. [CrossRef]

26. Köhl, M.; Neupane, P.R.; Mundhenk, P. REDD+ measurement, reporting and verification—A cost trap? Implications for financing REDD+MRV costs by result-based payments. Ecol. Econ. 2020, 168. [CrossRef]

27. Maroto, C.; Segura, M.; Ginestar, C.; Uriol, J.; Segura, B. Sustainable Forest Management in a Mediterranean region: Social preferences. For. Syst. 2013, 22, 546-558. [CrossRef]

28. PATFOR. Forestry Territorial Action Plan of the Valencian Community 2012. Generalitat Valenciana. Available online: http: / /agroambient.gva.es/auto/montes-bosques/PATFOR/01_MEMORIA/PATFOR_Memoria_version_final.pdf (accessed on 7 April 2021).

29. Delgado-Artes, R. Análisis de los Patrones de Evolución de las Coberturas Forestales en la Provincia de Castellón en los Últimos 50 Años. Ph.D. Thesis, Universitat Politècnica de València, Valencia, Spain, 2015. [CrossRef]

30. Giannakopoulos, C.; Bindi, M.; Moriondo, M.; LeSager, P.; Tin, T. Climate change impacts in the Mediterranean resulting from a $2^{\circ} \mathrm{C}$ global temperature rise. Rep. WWF 2005, 68, 209-224.

31. European Environment Agency (EEA). Corine Land Cover. 2018. Available online: https://land.copernicus.eu/pan-european/ corine-land-cover / clc2018 (accessed on 29 May 2020).

32. Montero, G.; Ruiz-Peinado, R.; Muñoz, M. Producción de Biomasa y Fijación de CO2 por los Bosques Españoles; Instituto Nacional de Investigación y Tecnología Agraria y Alimentaria, Ministerio de Educación y Ciencia: Madrid, Spain, 2005.

33. Lerma-Arce, V. Planificación, Logística y Valorización de Biomasa Forestal Residual en la Provincia de Valencia. Ph.D. Thesis, Universitat Politècnica de València, Valencia, Spain, 2015; p. 230.

34. McGroddy, M.E.; Daufresne, T.; Hedin, L.O. Scaling of C:N:P stoichiometry in forests worldwide: Implications of terrestrial Redfield-type ratios. Ecology 2004, 85, 2390-2401. [CrossRef]

35. Hughes, R.F.; Kauffman, J.B.; Jaramillo-Luque, V.J. Ecosystem-scale impacts of deforestation and land use in a humid tropical region of México. Ecol. Appl. 2000, 10, 515-527. [CrossRef]

36. Feldpausch, T.R.; Rondon, M.A.; Fernandes, E.C.M.; Riha, S.J. Carbon and nutrient accumulation in secondary forests regenerating on pastures in central Amazonia. Ecol. Appl. 2004, 14, S164-S176. [CrossRef]

37. Andreae, M.O.; Merlet, P. Emission of trace gases and aerosols from biomass burning. Glob. Biogeochem. Cycles 2001, 15, 955-966. [CrossRef]

38. Gayoso, J.; Guerra, J.; Alarcón, D. Contenido de Carbono y Funciones de Biomasa en Especies Natives y Exóticas; Universidad Austral de Chile: Valdivia, Chile, 2002.

39. Lamlom, S.H.; Savidge, R.A. A reassessment of carbon content in wood: Variation within and between 41 North American species. Biomass Bioenergy 2003, 25, 381-388. [CrossRef]

40. Tragsa, Empresa de Transformación Agraria. Tercer Inventario Forestal Nacional (IFN 3). 2006. Available online: https://www. miteco.gob.es/es/biodiversidad/servicios/banco-datos-naturaleza/informacion-disponible/ifn3_base_datos_26_50.aspx (accessed on 3 April 2020).

41. Life Forest CO2. 2019. Available online: http://lifeforestco2.eu/life-forest-co2-project/?lang=en (accessed on 13 April 2020). 
42. Woodland Carbon Code (WCC). United Kingdom. Published 9 July 2018. Available online: https://www.gov.uk/guidance/thewoodland-carbon-code-scheme-for-buyers-and-landowners (accessed on 13 April 2020).

43. Registro Huella de Carbono (RHC). Available online: https://www.miteco.gob.es/es/cambio-climatico/temas/mitigacionpoliticas-y-medidas/que_es_Registro.aspx (accessed on 13 April 2020).

44. Carbomark. Development of Policies for the Creation of local Voluntary Carbon Markets for Mitigating Climate Change. Project LIFE07 ENV/IT/000388. 2011. Available online: https:/ / ec.europa.eu/environment/life/project/Projects/index.cfm? fuseaction=home.showFile\&rep=file\&fil=CARBOMARK_Manual_EN.pdf (accessed on 1 June 2020).

45. Croitoru, L. How much are Mediterranean forests worth? For. Policy Econ. 2007, 9, 536-545. [CrossRef]

46. Plana, E.; Font, M.; Serra, M.; Borràs, M.; Vilalta, O. Fire and Wildfires in the Mediterranean; a Relationship Story between Forest and Society. Five Myths and Realities. Available online: http:/ / efirecom.ctfc.cat/docs/revistaefirecom_en.pdf (accessed on 7 April 2021).

47. Moreno, M.V.; Conedera, M.; Chuvieco, E.; Pezzatti, G.B. Fire regime changes and major driving forces in Spain from 1968 to 2010. Environ. Sci. Policy 2014, 37, 11-22. [CrossRef]

48. Corona, P.; Ascoli, D.; Barbati, A.; Bovio, G.; Colangelo, G.; Elia, M.; Garfi, V.; Iovino, F.; Lafortezza, R.; Leone, V.; et al. Integrated forest management to prevent wildfires under Mediterranean environments. Ann. Silvic. Res. 2015, 39, 24-45. [CrossRef]

49. Cabanes-Sanchez, M.; del Valle, E. El Carbono en los Ecosistemas Forestales Valencianos. 2016. Available online: http://www. plataformaforestalvalenciana.com/wp-content/uploads/2015/11/3\%C2\%AAcircular.pdf (accessed on 1 June 2020).

50. MITECO. Los incendios Forestales en España. Decenio 2006-2015. Ministerio para la Transición Ecológica y el Reto Demográfico, 2020. Madrid, Spain. Available online: https:/ /www.mapa.gob.es/es/desarrollo-rural/estadisticas/incendios-decenio-2006-201 5_tcm30-511095.pdf (accessed on 7 April 2021).

51. REMAS Project. Greenhouse Gas Emissions Risk Management in Wildfires. 2019-2022. Available online: http:/ /www.isa.ulisboa. $\mathrm{pt} /$ ceabn/projecto/2/101/remas-managing-the-risk-of-emissions-of-gases-with-greenhouse-effect-from-wildfires (accessed on 7 April 2021).

52. Hurteau, M.D.; Koch, G.W.; Hungate, B.A. Carbon protection and fire risk reduction: Toward a full accounting of forest carbon offsets. Front. Ecol. Environ. 2008, 6, 493-498. [CrossRef]

53. European Commission. Directive 2003/87/EC of the European Parliament and of the Council of 13 October 2003 Establishing a Scheme for Greenhouse Gas Emission Allowance Trading within the Community and Amending Council Directive 96/61/EC. Available online: https:/ / eur-lex.europa.eu/legal-content/EN/TXT/?uri=celex\%3A32003L0087 (accessed on 7 April 2021).

54. Oficina Española de Cambio Climático (OECC). Instalaciones Afectadas por la ley 1/2005 Informe de Aplicación del año 2018. Available online: https://www.miteco.gob.es/es/cambio-climatico/temas/comercio-de-derechos-de-emision/ley1_200 5-informeaplicacion2018_tcm30-497632.pdf (accessed on 5 May 2020).

55. Ecological Transition and Demographic Challenge Ministry. National Inventory of Emissions to the Atmosphere. GHG Emissions 1990-2018. March 2020. Available online: https://www.miteco.gob.es/es/calidad-y-evaluacion-ambiental/temas/sistemaespanol-de-inventario-sei-/es-2020-nir_tcm30-508122.pdf (accessed on 7 April 2021).

56. Tong, X.; Brandt, M.; Yue, Y.; Ciais, P.; Rudbeck Jepsen, M.; Penuelas, J.; Wigneron, J.P.; Xiao, X.; Song, X.P.; Horion, S.; et al. Forest management in southern China generates short term extensive carbon sequestration. Nat. Commun. 2020, 11, 129. [CrossRef]

57. Van Khuc, Q.; Le, T.-A.T.; Nguyen, T.H.; Nong, D.; Tran, B.Q.; Meyfroidt, P.; Tran, T.; Duong, P.B.; Nguyen, T.T.; Tran, T.; et al. Forest Cover Change, Households' Livelihoods, Trade-Offs, and Constraints Associated with Plantation Forests in Poor UplandRural Landscapes: Evidence from North Central Vietnam. Forests 2020, 11, 548. [CrossRef]

58. Lin, D.; Lin, Y. Stakeholders of Voluntary Forest Carbon Offset Projects in China: An Empirical Analysis. Adv. Meteorol. 2015, 7. [CrossRef] 